\title{
MODERN LANGUAGES AND DISTANCE EDUCATION: Thirteen Days in the Cloud
}

\author{
Associate Professor Elfe DONA, PhD. \\ German Modern Languages and Teacher Education \\ Wright State University \\ 3640 Colonel Glenn Hwy, \\ Millet Hall 335 Dayton, Oh 45435, USA \\ Assistant Professor Sheri STOVER, PhD. \\ Instructional Design \\ Wright State University \\ 3640 Colonel Glenn Hwy, \\ Allyn Hall 445 Dayton, Oh 45435, USA \\ Associate Professor Nancy BROUGHTON, PhD. \\ Spanish Modern Languages \\ Wright State University \\ 3640 Colonel Glenn Hwy, \\ Millet Hall 330 Dayton, Oh 45435, USA
}

\section{ABSTRACT}

This research study documents the journey of two modern language faculty (Spanish and German) from their original beliefs that teaching foreign languages can only be conducted in a face-to-face format to their eventual development of an online class using Web 2.0 technologies to encourage their students' active skills of reading and speaking in their target language. The research study shows how the instructors incorporated Web 2.0 technologies and used the Communities of Inquiry (CoI) framework to design their online class to ensure their class had the essential elements of teaching presence, social presence and cognitive presence. Web 2.0 technologies used to build strong levels of CoI were BB-Collaborate web conferencing, Voki, VoiceThread, ANVILL, Fakebook, Bubble,us, Mindmapping, Flashcard Exchange, Glogster, Zunal, and Weebly.

Keywords: Modern Languages, community of Inquiry, Web 2.0, distance education

\section{INTRODUCTION}

This research study originated with two faculty members in the Modern Languages department teaching German and Spanish who believed the only viable method for teaching foreign languages is in a face-to-face environment due to the unique teaching and learning requirements for modern languages. 
Both faculty members began to become intrigued by opportunities that could be realized by incorporating some of the newly developing Web 2.0 technologies to teach a second language (L2). Web 2.0 technologies are technologies that allow people to have rich and meaningful interactions while communicating online, in contrast to Web 1.0 technology that is static text-based web pages (O'Reilly, 2005).

The two faculty members also realized that the use of Web 2.0 technologies would allow them to develop distance education classes that included high-quality types of interactive pedagogies they demanded from their classes.

They knew that some aspects of the face-to-face class might be lost, but they also recognized that there would be many new opportunities realized by designing classes using Web 2.0 technologies in a distance education environment.

As their intrigue with the Web 2.0 technologies continued to develop, they began to educate themselves about the possibilities of utilizing these Web 2.0 and Distance Education (DE) technologies in their Modern Language classes (Prensky, 2010; Pegrum, 2009). The professors began to attend workshops in their university's Center for Teaching and Learning (http://www.wright.edu/ctl) on topics such as learning management systems, virtual worlds, gaming, distance education, video creation and other topics. To understand the pedagogy of these new Web 2.0 technologies they completed courses in their College of Education's Instructional Design for Online Learning (http://www.wright.edu/idol) program. They also began to attend conferences and reviewed the literature on the development of research in the area of incorporating Web 2.0 technologies and the development of Distance Education for teaching modern languages.

The literature they reviewed showed examples where students' learning in modern languages DE classes has proven successful (Blake \& Delforge, 2006; Chenoweth \& Murday, 2003, Hanbay \& Myo, 2013). The two faculty members learned about the rich, interactive Web 2.0 tools they could incorporate into their class that would allow students to focus on the active skills of speaking and writing in the literature they were reading (Thorne, Black \& Sykes, 2009). They also learned about the Community of Inquiry Framework that can be used to develop online courses to ensure the class works as a community and has the essential elements of teacher presence, social presence, and cognitive presence in the class (Garrison, Anderson, \& Archer, 2000).

The two Modern Language faculty members eventually became confident that the Web 2.0 technologies would allow them to include the rich interaction in a distance education class that they needed to teach a foreign language.

Despite reservations from many of their colleagues in the Modern Languages department, the two Modern Language professors opted to develop a summer distance education course for their undergraduate and graduate German and Spanish students.

The professors designed "Thirteen Days in the Cloud" as an intensive thirteen-day summer online course for both undergraduate and graduate German and Spanish students. Participants in the class used hands-on experience to create digital projects they could use with their future students or in the work place. 
The professors incorporated many new Web 2.0 technologies and applied the CoI framework to the design of this class. The professors wanted to incorporate the Web 2.0 technologies to emphasize the active skills of speaking and writing that are challenging to include in an online course.

The research questions for this action study research paper are:

$>$ Can Web 2.0 tools be used in a Modern Languages distance education class designed using the Community of Inquiry (CoI) framework that has strong levels of teaching presence, social presence, and cognitive presence?

$>$ How will students perceive participating in an online language class designed using the CoI framework to maximize teaching presence, social presence and cognitive presence?

$>$ Literature Review

While Distance Education is growing (Allen \& Seaman, 2013), many faculty teaching foreign languages still opt for the traditional face-to-face format because many online courses are heavily developed with text communication that resembles a high-tech correspondence course and does little to encourage interaction needed to provide effective instruction for Modern Languages (Crawford, 2006). The Modern Languages Association (MLA) and the AAUP question the use of distance education for teaching Modern Languages when they state that there are unique demands for teaching language that need to employ pedagogical strategies that go beyond mere acquisition of linguistic knowledge and require students to negotiate meaning to speak, listen, read and write in a foreign language. They go further to say that "this learning process requires a high level of human contact, one that is traditionally facilitated by face-to-face interaction in the language classroom" (MLA Executive Council, 2001, para 3). Distance education is courses in which $\mathbf{8 0} \%$ or more of the content is delivered online (Allen \& Seaman, 2013). The terms distance education and online education will be used interchangeably in this research paper.

Teaching foreign languages requires significant and meaningful interaction between the instructor and student where there is a community of learners working together to inquire about the discipline of learning a new language. Garrison (2011) defines an educational community of inquiry as a "group of individuals who collaboratively engage in purposeful critical discourse and reflection to construct personal meaning and confirm mutual understanding" (p. 15). To create successful educational communities of inquiry, instructors need to prepare learning environments that include ample opportunities where participants are actively engaged in the content using pedagogically effective teaching methodologies (Garrison, 2011).

Worthwhile education experiences are composed of teachers and students interacting in the three essential elements of teaching presence, social presence and cognitive presence (Garrison, Anderson, and Archer, 2000). Teaching presence (TP) is defined as the design and facilitation of the cognitive and social processes for students to be able to construct meaningful learning outcomes (Anderson, Rourke, Garrison, \& Archer, 2001). TP is measured by looking at the categories of

$>$ design and organization,

$>$ facilitation and

$>$ direct instruction. 
Social presence (SP) is defined as "the ability of participants in a community of inquiry to project themselves socially and emotionally, as 'real' people (i.e. their full personality), through the medium of communication being used" (Garrison, Anderson \& Archer, 2000, p. 94). SP is measured by looking at the categories of,

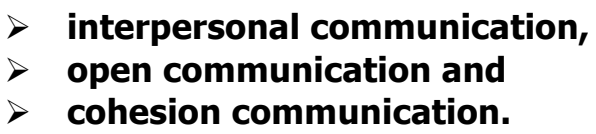

Cognitive presence (CP) is at the core of education and is defined "as the extent to which learners are able to construct and confirm meaning through sustained reflection and discourse in a critical community of inquiry" (Garrison, Anderson \& Archer, 2001, p. 11). $\mathrm{CP}$ is measured by looking at the categories of;

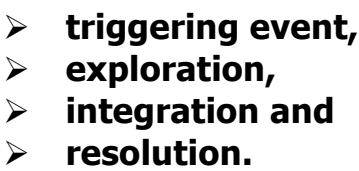

Table: 1

Community of Inquiry Categories and Indicators

\begin{tabular}{ll}
\hline Presences & Categories \\
Teaching Presence & $\begin{array}{l}\text { Design and organization } \\
\text { Facilitation } \\
\text { Direct instruction }\end{array}$ \\
\hline Social Presence & $\begin{array}{l}\text { Interpersonal communication } \\
\text { Open communication } \\
\text { Cohesive communication }\end{array}$ \\
\hline Cognitive Presence & Triggering event \\
& Exploration \\
& Integration \\
& Resolution \\
\hline & Note. Adapted from D. R. Garrison (2011) \\
& E-Learning in the 21
\end{tabular}

\section{METHOD}

\section{Participants}

The composition of this course differed widely from a traditional language classes. Two educators conducted this online course specializing in two different foreign languages. Participants in this class were undergraduate and graduate German and/or Spanish students in the Modern Languages department at a mid-sized university located in the Midwest. The class consisted of eighteen students. Of the 18 students, 14 were Spanish students consisting of 11 undergraduates (11 female), 3 graduates (1 male, 2 female), and four were German students, 3 undergraduates ( 2 male, 1 female), 1 graduate (1 male). The demographics show a wide age range of 21-55 years old. All students in this online course lived within a 50-mile radius of the university. They were enrolled in the Bachelor of Arts program in German or Spanish, or enrolled in the Master of Education Graduate Program. 
Most of the students indicated they had taken online classes before $(\mathrm{N}=10)$ and some students had not taken any online classes before $(\mathrm{N}=8)$.

\section{Environment}

This class was an upper-level course with two primary objectives:

$>$ to provide an introduction to some essential Web 2.0 tools and their usage for language teaching and learning. Students were to locate and analyze multi-media materials (video clips, blogs, TV clips, etc.) and interactive web tools (social media, collaborative tools, virtual language labs, etc.) and to explore how they could aid the learning process with more enthusiasm and

$>$ to instruct students to improve their level of language skills (listening, reading, speaking, writing).

The course was partially delivered in English and also in the target languages of German and Spanish.

The first and the last day of the course was taught in a face-to-face format, but the majority of the class was taught online. The class was offered in the summer, so it was taught in a condensed 13-day format. The course included days where the class used BB-Collaborate web conferencing to meet synchronously (live) and there were days where students worked independently on their own projects.

Web conferencing is a tool that allows participants to log onto to a session at the same time from different locations. The only requirement for participants to attend the web conference session is that they have an access device (computer, iPad, Smartphone) and availability to the Internet. Web conferences have tools that allow participants to communicate through voice, text chat, whiteboards (for writing), whiteboards (to upload PowerPoint slides), polling, emoticon expressions and breakout rooms.

The online course was structured according to the CoI framework. This model has been applied to other fields of study such as health care (Carlon, Bennett-Woods, Zenoni, et.al., 2012) and business education (Daspit, 2012; DeSouza 2012), but these researchers have found few studies that apply the complete CoI model (teaching presence, social presence and cognitive presence) to foreign language learning.

The Web 2.0 tools that were selected for this course were picked to allow students to develop the active skills of speaking and writing in their target language. The Web 2.0 tools incorporated in the course were accessible to students at no charge and they were tools that students could utilize again in their personal lives and/or professional careers.

ProceduresData for this research study was gathered from the course instructors, students enrolled in the course, and a review of the course material. Data about how the instructors designed the class using the CoI framework was gathered through:

$>$ interviews with the class instructors,

$>$ review of the course documents such as the syllabus, calendar, and assignments, and

$>$ self-reflection of the instructors. 
A list of course activities was compiled and then separated into activities that supported the development of TP, SP, or CP. The activities were further assigned to the categories for each of the presences (see Table: 1). At the end of the course students were asked to fill out an anonymous paper-and-pencil survey during the last face-to-face class (see Table \# 2). There were 18 of the 19 students that completed the survey. The researchers used NVivo 10 qualitative data analysis software to analyze and classify the student comments. Student comments were broken down into one of the three CoI presences of TP, SP, or CP. If student comments fit more than one presence, they were added to all that applied. The comments were further assigned to the CoI categories for each of the presences (see table \#1). Comments were coded as positive or negative. Student comments in each category were grouped in attempt to find common themes.

Table: 2

Student Survey Questions

Why did you take this class?

Would you take another interactive language class online? Why or why not?

Do you think that the ratio of online and offline classes was effective and balanced?

Why or why not?

Should this be a core course for language learners? At what level should it be offered?

Was the class size too large or too small? Explain.

Was team-teaching a good idea? Why or why not?

What was the most challenging aspect of this class?

What one big idea did you take from this class?

Do you think that you can use this knowledge elsewhere?

\section{DATA RESULTS}

\section{Research Question 1}

The first research question asks if Web 2.0 tools can be used in a Modern Languages distance education class designed using the Community of Inquiry (CoI) framework to ensure the course has strong levels of teaching presence, social presence, and cognitive presence. Here are the tools the instructors used to ensure these three presences were maximized in the course (see Appendix).

\section{Teaching Presence}

TP takes a look at the presence of the instructor in an online course while they manage and monitor the learning community. Teaching presence is measured by looking at the three categories of (1) design and organization, (2) facilitation and (3) direct instruction (Garrison, 2011).

\section{Design and Organization}

Students were required to meet face-to-face with faculty for the first and last class sessions. This was possible since students enrolled in this class were from the local area. Students were given the option to attend through web conferencing if they could not attend face-to-face, but this was not necessary. The design and organization of the course were defined and discussed in the first class and students were trained to use the learning management system (LMS) and the web conferencing tool that would be used to conduct the other classes. 
The BB-Collaborate sessions were broken out into three parts. The first part of the class started in one big group to learn the digital Web 2.0 tools. In the second part of the class, students would break out into groups and speak only in Spanish or German to apply those Web 2.0 tools. For the final part of the class, the entire class would reconvene at the end of the web conference session to debrief.

\section{Facilitation}

On the first day of class, students wrote a reflection paper about their current knowledge and use of Web 2.0 technologies. Based upon those findings, the course was aligned with the appropriate Web 2.0 apps. The professors facilitated learning by giving students the tools to learn about technology with tutorials, scholarly articles, Internet resources and assigning students to groups to allow for peer-to-peer collaboration. Students used these resources to teach themselves how to use the Web 2.0 technologies. The instructors monitored their progress, answered questions, and got students back on track when needed.

\section{Direct instruction}

Since web conferencing classes were an integral part of the class, the instructors had the opportunity to provide lots of direct instruction. The first part of each web conference class was dedicated to review and clarify previous topics, problems, and applications. It also served as a forum so that students could ask questions in English and professors and peers could respond. They also had the opportunity to use their newfound knowledge of Web 2.0 technologies to guide other students. While students went to their virtual breakout rooms during the second part of the web conference class, the instructors moved virtually through the breakout rooms to monitor student progress and clear up any misunderstandings. During this time, students had the opportunity to become the teacher by offering peer reviews in the target language. During the third part of the web conference class, the instructors had the opportunity to provide direct instruction again since this time was spent to allow groups to summarize and share their findings. The professors could use this time to resolve any conflicts or provide feedback. The professors continued their direct instruction with students outside the class by interacting with students through e-mail or online office hour meetings through BBCollaborate. It was important to establish a sense of community among both students and professors that is often challenging to create and maintain in a DE course.

\section{Social Presence}

Social presence takes a look at the welcoming environment in a DE class to see if participants can collaborate effectively as a learning community using the tools in the DE classroom. Social presence is measured by looking at the three categories of:

$>$ interpersonal communication,

$>$ open communication and

$>$ cohesion communication (Garrison, 2011).

Creating a strong sense of social presence is critical to the success of teaching foreign languages since students are often reluctant to express themselves in another language for fear of committing mistakes or of embarrassing themselves.

This can be an obstacle to learning, practicing and teaching a language. 
Learners must be motivated and emotionally connected to the content to have a deep learning experience (Bowen, 2012). They also must feel a sense of collaboration and togetherness although they are physically separated. The professors focused on establishing a safe social community through synchronous web conference and asynchronous sessions. The asynchronous sessions gave the students time to reflect and discuss topics through forums posted on the LMS to feel better prepared and more comfortable discussing the topics during the live web conference sessions. When not in live web conference sessions, students researched the Web 2.0 apps and then created projects.

\section{Interpersonal Communication}

The majority of the digital Web 2.0 technologies that students used in this class were selected to foster creativity while learning a foreign language. An example of this was the Voki app (http://www.voki.com), where students established social presence through the creation of personalized speaking avatars.

While becoming a digital avatar, students had the freedom to express their self-identity in a risk free virtual environment. Each student posted a short autobiographical presentation and then other avatars could respond in a safe place with humor and dignity. The LMS also provided tools such as discussion and email where students could interact and become emotionally connected to their classmates. Students could also show support to each other during the live web conference sessions by using their emoticons of "thumbs up", "smiley face" or "applause" to give each other encouragement and support.

\section{Open Communication}

The professors chose digital Web 2.0 technologies that exemplified open communication in foreign language learning. An example of this was VoiceThread (http://voicethread.com) which is a Web 2.0 technology that allows people to post media artifacts and then members of the community can provide feedback. They selected VoiceThread as an ideal app and expanded the idea of self-expression to give others the chance to become part of the project. Students were assigned to create a "virtual" trip that included representative photos and their audio narration. Their peers then added their recorded responses. Another Web 2.0 technology that was used to allow for open communication was ANVILL (https://anvill.uoregon.edu/anvill2), which is a speechbased toolbox designed for language teachers. Students could create and post audio and video files to illicit responses from their peers. Fakebook (http://www.classtools.net/fb/home/page) is another Web 2.0 technology that allows for open communication where students created their own "fake" Facebook-like page under a different identity, such as an historical or literary figure. Students were invited to become "friends" in the social network. The LMS also offered a discussion board that encouraged communication in the class and also strengthened group cohesion.

\section{Cohesive Communication}

A major challenge in this online course was the diverse makeup of the class. Students differed by the language being learned, maturity, grade-level, and skill level and interests. To draw from all levels of expertise, the professors created a discussion board that the students "owned". Without penalty or judgment by the professors, students could freely post thoughts, comments, references, and issues in the target language. 
In thirteen days, 18 students posted every other day in the L2, demonstrating the motivation to express themselves. Participation was not mandatory, and individual responses varied from as little as two responses to twenty responses. Students would use this discussion board to query for "help" when they had difficulties understanding the tutorials while learning the Web 2.0 technologies. Students learned to rely on each other for help and support instead of depending on receiving everything from the instructors. If the problem could not be resolved, the professors guided the students in the following class.

\section{Cognitive Presence}

Cognitive presence is at the core of educational experiences. It is critical that students realize higher-order thinking and engage in rich discourse in an online class (Garrison, 2011). Cognitive presence is measured by looking at the four categories of

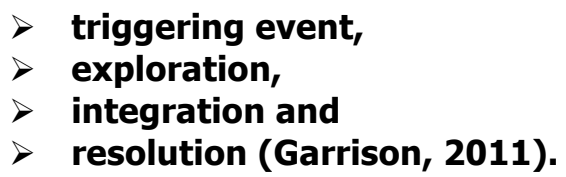

Triggering Event

A triggering event establishes a sense of puzzlement that initiates the process of deep learning (Garrison, Anderson \& Archer, 2000). To get students excited about each live web conference class, the session began with an overview of a Web 2.0 technology that sparked students' interest. The instructors would give a quick overview, provide tutorials and then put the responsibility for learning how to use and apply the Web 2.0 technology in the hands of the students. Students were encouraged to assume responsibility for taking on the challenges of independent learning to help them become life-long learners with 21st century skills. For example, the professors created a short video through Animoto (http://www.animoto.com) that showcased the advantages of applying Web 2.0 tools to foreign language learning.

\section{Exploration}

In this class, exploration was manifested in the use of many tools, such as Fakebook (http://www.classtools.net/fb/home/page), Bubbl.us (http://www.bubbl.us.com), and Mindmapping (http://www.mindmapping.com). Bubbl.us and Mindmapping serve as a brainstorming tool to list and categorize various ideas. Fakebook fwas used or more complex exploration as the students created their own imaginary "facebook" page of historical figures and places. One student showed her creativity by personalizing Austria.

The Fakebook became a source of collaboration and lively discussion in the target language without criticism. The content for this class did not come out of a textbook, which led to stronger social presence as the students needed to rely on other students' contributions and ideas, stressing the importance of cohesion, collaboration and research.

Students were provided with multiple resources, such as scholarly articles, websites and tutorials. Students had multiple options to find the best resources that met their learning styles that allowed them to explore the material and discover the information that would best meet their needs. 


\section{Integration}

Each task and Web 2.0 tool was based on Bloom's revised taxonomy (Krathwohl, 2002) where assignments began at the lower levels of learning, such as remembering and understanding by using Web 2.0 technologies, for example, Flashcard Exchange (http://www.flashcardexchange.com). Assignments progressively were guided toward the deeper-thinking skills of applying, analyzing, evaluating, and creating. For example, Glogster (http://www.glogster.com) allowed the students to create interactive multimedia posters.

\section{Resolution}

From the first day students were aware that all tasks of the class would lead to a culminating final project. Throughout the course, students collaborated with peers and the professors through discussion boards, online office hours, breakout sessions, feedback and reflection papers. Offline class sessions offered the students the opportunity to research, process information, edit, reflect and apply new ideas and concepts.

Students created a culminating final project where they showcased their best work in a WebQuest using Zunal (http://www.zunal.com) or Weebly (http://www.weebly.com). A WebQuest serves as an online webpage that allows students to collect, explore and evaluate information. Zunal and Weebly act as a repository of multimedia projects, writings and web tools.

The WebQuest emphasizes deeper thinking skills. Students analyzed various Web $\mathbf{2 . 0}$ tools and scholarly articles, and they were required to show how they would apply their creations in their learning or teaching environment.

The projects were not isolated to self-learning as peers and professors provided feedback and criticism, and had access to the projects for further learning opportunities.

The WebQuests demonstrated two outcomes. As this was a repository of the students' edited work, the professors could see the improvements in L2 proficiency.

Secondly, the WebQuests, along with reflection papers and a post-course survey showed evidence that students were able to apply new concepts to their objectives and needs.

Although the course was intensive due to time constraints, students were able to accomplish tasks and perform at a high level.

From the survey, students commented that although activities were strenuous, they felt that their newfound skills would be applicable to their lives and in the future they would use these skills as 21st century learners.

\section{Research Question 2}

The second research question asks how students will perceive participating in an online language class designed using the $\mathrm{CoI}$ framework to maximize teaching presence, social presence and cognitive presence. Data were gathered from the end-of-the course student-survey. 
Teaching Presence

All of the comments that students made about TP were in the category of design and organization. Students had more than 5.6 times more positive comments (73 references) about TP than negative (13 references). Most students felt the design of the class was fun and interesting (21 references) with comments such as "It was very interesting and a great tool to learn". There were also many students that enjoyed the incorporation of the technology (19 references) with "I absolutely loved the technology aspect of the class. In my 5 years at Wright State, it was my favorite". Students also enjoyed the flexibility of an online class (18 references) with comments such as "I wanted to finish my minor before next fall and I really like online classes". While there were few negative TP comments, the ones in the area were student comments on the fact that the course was offered in a condensed 13-day format and had concerns over the quickness (9 references) with comments such as "The most challenging aspect of this class was finding the time to cram 10-weeks' worth of work into 2 weeks".

\section{Social Presence}

All of the comments that students made about SP were in the category of group cohesion. Students had more than 5.6 times more positive comments (17 references) about the SP in the class than negative (3 references). Most students felt the online groups worked well together (10 references) with comments such as "If the person didn't know how to do something, then the other person might know". Students also reported enjoying interacting with each other (5 references) with comments such as "I loved the opportunity to share ideas and speak in Spanish". There were very few negative comments about the SP in the class, but those comments focused on the wish to have more opportunities to meet in a face-to-face format ( 3 references) with comments such as "Not being able to meet face-to-face to discuss problems".

\section{Cognitive Presence}

All of the comments that students made about CP were positive ( 25 references). The most common CP category students commented on was their ability to explore. Students commented on their enjoyment of being able to explore technologies that they feel would be useful for them in the future (17 references) with comments such as "I definitely think that I will use this knowledge in the future when I begin to teach. The class has given me lots of ideas". The second highest CP category students commented on was the triggering events where students said the format of the class was fun and got them exited ( 3 references) with comments such as "It was fun and a different way to learn".

\section{DISCUSSION}

This class posed very few challenges. At times students became frustrated when technology failed them. Students were dropped from sessions when the Internet connection failed. Some students also seemed to show a low tolerance for learning new technologies. When a tutorial was not explicit enough, some students tended to give up. Although students collaborated well, there were always a small number that did not participate fully, especially near the end of the course when students were fatigued. Discussion board comments decreased near the end of the session. Although challenges existed, the CoI model acted as the compass to navigate the course. "Thirteen Days in the Cloud" provided evidence that teaching presence, social presence and cognitive presence can be achieved in a DE foreign language class. 


\section{CONCLUSIONS}

Initially the researchers were skeptical if distance education could provide a learning environment that was suitable to teach German and Spanish. With the incorporation of newly developing Web 2.0 technologies and the incorporation of the CoI framework to design the course, the instructors felt that they were successful in designing an effective online class that had a strong sense of teaching presence, social presence and cognitive presence. At times students became frustrated when they experienced technology glitches, but they were able to work through the issues and produced high quality student products. Based on this experience, the researchers conclude that Web 2.0 tools can be used to develop an online class using the Community of Inquiry (CoI) framework to ensure there is an active community of learners that has strong levels of teaching presence, social presence, and cognitive presence. Students indicated they had positive levels of teaching presence, social presence, and cognitive presence while participating in the course. Being able to take an online class over the summer allowed students to have the flexibility they needed to continue taking classes and they enjoyed the interaction and feedback they received using the Web 2.0 technologies.

\section{STUDY LIMITATIONS AND RECOMMENDATIONS}

This research study took place in one online class that included 18 students, so the results cannot be generalized to all modern language learning environments. We recommend that Modern Language faculty begin to investigate the incorporation of Web 2.0 technologies into foreign language learning and we believe that other instructors will also realize the potential to use these technologies to encourage their students' active skills of reading and speaking in their target language. We would also encourage faculty to investigate the development of their classes using the CoI framework. Lastly, we would encourage Modern Language faculty to begin considering the development of DE classes to give students the flexibility in learning that students are looking for.

\section{BIODATA and CONTACT ADDRESSES of the AUTHORS}

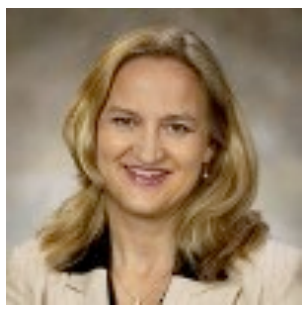

Elfe DONA, PhD. is an Associate Professor in Modern Languages at Wright State University and teachers classes in German. Nancy Broughton, PhD. is an Associate Professor in Modern Languages at Wright State University and teachers classes in Spanish. Sheri Stover, PhD. is an Assistant Professor in the College of Education and Human Services at Wright State and teaches classes in Instructional Design.

Elfe Dona, PhD.

Associate Professor

German Modern Languages and Teacher Ed

Wright State University

3640 Colonel Glenn Hwy, Millet Hall 335 Dayton, Oh 45435, USA

Phone: (937) 775-2600

Email: elfe.dona@wright.edu 


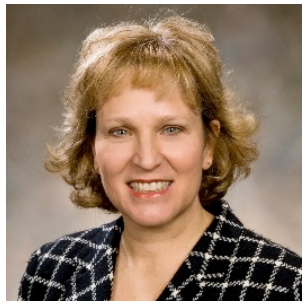

Sheri STOVER Sheri Stover, PhD is an Assistant Professor at Wright State University and teaches Instructional Design in the Leadership Studies in Education and Organizations department. She has worked as an Instructional Designer for two Ohio universities. She was also the president of a computer training company. Dr. Stover also holds numerous Quality Matters certifications including APPQMR, Peer Review, and Face-to-face facilitation.

Assistant Professor Sheri STOVER, PhD.

Instructional Design

Wright State University

3640 Colonel Glenn Hwy,

Allyn Hall 445 Dayton, Oh 45435

Phone: (937) 775-3008

Email: elfe.dona@wright.edu

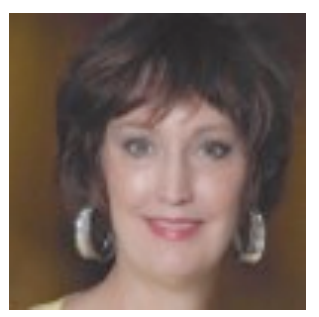

Nancy BROUGHTON PhD. is an Associate Professor of Spanish at Wright State University. She received her degrees from Michigan State University and the University of Notre Dame.

Her interests include teaching pedagogy, Distance Education, and international business. She also created and taught the first online courses in the Department of Modern Languages at Wright State University, Ohio.

Nancy BROUGHTON, PhD.

Associate Professor of Spanish Modern Languages

Wright State University

3640 Colonel Glenn Hwy,

Millet Hall 330 Dayton, Oh 45435, USA

Phone: (937) 775-2153

Email: nancy.broughton@wright.edu

\section{REFERENCES}

Allen, I. E., \& Seaman, J. (2013). Changing course: Ten years of tracking online education in the United States. Babson Survey Research Group and Quahog Research Group, LLC. Retrieved from http://www.onlinelearningsurvey.com/reports/changingcourse.pdf

Anderson, T., Rourke, L., Garrison, D. R., \& Archer, W. (2001). Assessing teacher presence in a computer conferencing context. Journal of Asynchronous Learning Networks, 5(2), 1-17.

Blake, R., \& Delforge, A. M. (2006). Online language learning: The case of Spanish without walls. In B. Lafford \& R. Salaberry (Eds.). The art of teaching Spanish: Second language acquisition from research to praxis. Washington, DC: Georgetown University Press. 
Bowen, J. (2012). Teaching Naked: How moving technology out of your college classroom will improve student learning. San Francisco, California: Wiley.

Carlon S, Bennett-Woods D, Zenoni L, et al. The Community of Inquiry Instrument: Validation and Results in Online Health Care Disciplines. Computers \& Education [serial online]. September 1, 2012;59(2):215-221. Available from: ERIC, Ipswich, MA. Accessed August 17, 2013.

Chenoweth, N. A., \& Murday, K. (2003). Measuring student learning in an online French course. CALICO Journal, 20(2), 285-314.

Crawford, D. L. (2006). Characteristics leading to student success: A study of online learning environments. Texas A\&M University- Commerce, United States-Texas: Ed.D. Dissertation.

Daspit, J. J., \& D'Souza, D. E. (2012). Using the community of inquiry framework to introduce wiki environments in blended-learning pedagogies: Evidence from business capstone course. Academy Of Management Learning \& Education, 11(4), 666-683.

Garrison, D. R., Anderson, T., \& Archer, W. (2000). Critical inquiry in a text-based environment: Computer conferencing in higher education. The Internet and Higher Education, 2(2-3), 87-105.

Garrison, D. R., Anderson, T., \& Archer, W. (2001). Critical thinking, cognitive presence and computer conferencing in Distance Education. American Journal of Distance Education, 15(1), 7-23.

Garrison, D. R. (2011). E-Learning in the 21st Century: A framework for research and practice. Second Edition. New York: Routledge.

Hanbay, 0. (2013). Relationship between web-based learning time outside the classroom and academic achievement in German as a tertiary language by the students on vocational high schools. Turkish Online Journal of Distance Education-TOJDE, 14(1), 29-34.

Krathwohl, D. R. (2002). A revision of bloom's taxonomy: An overview. Theory into Practice, 41 (4), 212-218.

MLA Executive Council. (2001, February 23-24). Special considerations for language and literature: The AAUP Statement on Distance Education. Retrieved from the MLA web site @ http://www.mla.org/statement_aaup_distance_ed

O'Reilly, T. (2005). What is Web 2.0: Design patterns and business models for the next generation of software? O'Reilly Network. Retrieved from http://oreilly.com/web2/archive/what-is-web-20.html

Pegrum, M. (2009). From blogs to bombs the future of digital technologies in education/Crawley, W.A. UWA Pub. 
Prensky, M. (2010). Teaching digital natives: Partnering for real learning. Thousand Oaks, California: Corwin.

Stevenson, M. P., \& Liu, M. (2010). Learning a Language with Web 2.0: Exploring the Use of Social Networking Features of Foreign Language Learning Websites. CALICO Journal, 27(2), 233-259.

Thorne, S. L., Black, R. W., \& Sykes, J. M. (2009). Second language use, socialization, and learning in internet interest communities and online gaming. The Modern Language Journal, 93, 802-821. 
Enclosed are the Web 2.0 tools used to ensure TP, SP, and CP.

Teaching Presence

BB-Collaborate web conferencing

https://www.blackboard.com/platforms/collaborate/overview.aspx

Desire2Learn

http://www.desire2learn.com/

Social Presence

BB-Collaborate web conferencing

https://www.blackboard.com/platforms/collaborate/overview.aspx

Desire2Learn

http://www.desire2learn.com/

Voki

http://www.voki.com/

Voice Thread

http://voicethread.com/

ANVILL

https://anvill.uoregon.edu/anvill2/

Fakebook

http://www.classtools.net/FB/home-page

Cognitive Presence

BB-Collaborate web conferencing

https://www.blackboard.com/platforms/collaborate/overview.aspx

Desire2Learn

http://www.desire2learn.com/

Fakebook

http://www.classtools.net/FB/home-page

Bubbl.us.com

http://ww2.bubbl.us.com/

Mindmapping.com

http://www.mindmapping.com/

Flashcard exchange (now Cram.com)

http://www.cram.com/

Glogster

http://www.glogster.com/

Zunal

http://www.zunal.com/

Weebly

http://www.weebly.com/ 